\title{
Sources of Primary Inoculum of Botrytis cinerea and Their Impact on Fungicide Resistance Development in Commercial Strawberry Fields
}

\author{
Michelle Souza Oliveira, Gulf Coast Research and Education Center, University of Florida, Wimauma 33598; Achour Amiri, Tree Fruit \\ Research and Extension Center, Washington State University, Wenatchee 98801; and Adrian I. Zuniga and Natalia A. Peres, ${ }^{\dagger}$ Gulf Coast \\ Research and Education Center, University of Florida, Wimauma 3598
}

\begin{abstract}
Strawberry transplants produced in nurseries across Canada, northern United States, and California are shipped annually to other strawberrygrowing regions, including Florida. Botrytis cinerea, the causal agent of gray mold, causes latent infections on transplants which are suggested as a potential source of primary inoculum in strawberry fields. In this study, we investigated the survival of $B$. cinerea isolates over the summer in Florida, the presence of $B$. cinerea in transplants from 14 nurseries from Canada and the United States in 2011, 2012, and 2013, and the sensitivity of nursery population to several botryticides. Botrytis cinerea was detected on dead strawberry plants sampled from commercial strawberry fields between March and June but not in July and August, suggesting

that the fungus does not over-summer in strawberry fields in Florida Nursery transplants surveyed in 2011, 2012, and 2013 showed B. cinerea incidences of 20 to 37,20 to 83 , and 2.5 to $92.5 \%$, respectively. In total, 409 isolates were tested for sensitivity to pyraclostrobin, boscalid, pyrimethanil, fenhexamid, iprodione, penthiopyrad, fluopyram, and fludioxonil. Overall, respective resistance frequencies were 91.7, 79.3, 33.2, 20.7, 2.4, 0.2, 0.2, and $0.0 \%$. A majority of isolates tested were resistant to either 3 or 4 fungicides simultaneously. These findings reinforce the need for an integrated approach between strawberry nurseries and production fields to improve gray mold management and mitigate future risks of resistance development in B. cinerea.
\end{abstract}

Strawberries are grown as a winter annual crop in Florida. Transplants are produced in nurseries across Canada, the northern United States, and California and acquired by growers every season. Florida strawberry production starts with soil preparation with fumigation to suppress nematodes, weeds, and soil-borne pathogens (Gilreath et al. 2006). Bare-root transplants are then planted on raised beds covered with black plastic mulch, usually at a density of 39,500 to 54,400 plants per hectare (Whitaker et al. 2015). To reduce production costs, many strawberry growers are reusing the prepared beds for more than one season. Consequently, plants are killed at the end of the season, sometime in March or April, but are not removed from beds until just prior the beginning of following season, late September, when new transplants are used. This practice is suggested to be a potential source of inoculum for several pathogens if they can over-summer between seasons.

Gray mold, caused by Botrytis cinerea, is one of the most important diseases of strawberry that affects flowers and fruit, causing preand postharvest decay. The symptoms on fruit begin with a small, firm, light-brown lesion that enlarges quickly and becomes covered with a gray, fuzzy mass of spores (Sutton 1998). Gray mold in Florida strawberry fields is controlled primarily by fungicide applications. The current management program includes weekly applications of multi- and single-site fungicides as rotations or tank mixtures, with sprays of the multisites captan and thiram throughout the season, and application of single-sites during peak bloom periods when weather conditions are favorable. Timing of fungicide applications has been improved in recent years by targeting potential gray mold epidemics predicted by the Strawberry Advisory System (Amiri and Peres 2014; MacKenzie and Peres 2012; Mertely et al. 2002).

Five groups of fungicides with different modes of action are labeled to control B. cinerea in Florida, including SDHIs (succinate dehydrogenase inhibitors), QoIs (quinone outside inhibitors),

${ }^{\dagger}$ Corresponding author. E-mail: nperes@ufl.edu

This material is based upon work that is supported by the National Institute of Food and Agriculture, U.S. Department of Agriculture, under award number 2014-51181-22377.

Accepted for publication 15 June 2017

C 2017 The American Phytopathological Society
AP (anilino-pyrimidines), PP (phenylpyrroles), and the sterol biosynthesis inhibitor Hyd (hydroxyanilides) (Amiri et al. 2013; FRAC 2015). Resistance of $B$. cinerea to most of these fungicides has already been reported from Germany (Grabke and Stammler 2015), Greece (Myresiotis et al. 2007), France (Leroux et al. 2010), Chile (Esterio et al. 2011), and several U.S. states (Amiri et al. 2013; Fernandez-Ortuno et al. 2014; Kim and Xiao 2010; Mercier et al. 2010), including Florida. The widespread distribution of $B$. cinerea with resistance to multiple fungicides simultaneously (Amiri et al. 2013; Fernandez-Ortuno et al. 2014) limits the number of fungicides available for an effective disease management.

Quiescent infections of $B$. cinerea on transplants have also been suggested as a potential source of primary inoculum in strawberryproducing regions (Mercier et al. 2010; Oliveira et al. 2013; Oliveira and Peres 2014). Despite their healthy appearance, certified plants can carry quiescent infections of $B$. cinerea as well as other pathogens. Recommendations ensure the use of broad-spectrum fungicides in nurseries to lower selection pressure on pathogen populations. However, some of the fungicides sprayed by the fruit growers are also used in nurseries to produce supposedly disease-free transplants. Thus, it is possible that populations of $B$. cinerea resistant to fungicides used in the nurseries are being continuously introduced to growing regions as quiescent infections via transplants.

Therefore, the objectives of this study were to: (i) verify the survival of $B$. cinerea on strawberry plants left in the fields over the summer in Florida; (ii) survey transplants from various nurseries in the United States and Canada for quiescent infections of $B$. cinerea; and (iii) determine the sensitivity profile of the primary inoculum of $\mathrm{B}$. $\mathrm{cin}$ erea populations carried over the transplants to selected fungicides commonly used to control gray mold in Florida strawberry fields.

\section{Materials and Methods}

Over-summering of $B$. cinerea in strawberry fields. Plant material consisting of whole dead strawberry plants were collected from commercial strawberry fields in Florida at the end of the regular growing season for two consecutive years. Plants were collected on 14 August 2012 from two commercial fields located in Hillsborough County and in 2013 monthly, from April to August, from one field (LFL) located in Citrus County and three fields (CER, RFR, NIT) in Hillsborough County. Forty plants were collected from each commercial field at each sampling period. Whole plants (dead leaves, stems, and mummies), were randomly pulled in a way to leave 50 buffer 
plants between sampled plants within each row bed and 10 row-buffer beds between the four replication beds used for sampling. Plants were placed individually in labeled plastic bags and transferred to the lab for further analysis. Plant were chopped into small 5- to $10-\mathrm{mm}$ pieces using a pruner, previously sterilized in ethanol, and samples were stored in sterile 50-ml tubes at $4^{\circ} \mathrm{C}$.

The recovery and enumeration of Botrytis propagules were conducted on a Botrytis-selective medium (BSM) consisting of (in g/liter): glucose, 2; $\mathrm{NaNO}_{3}, 0.1 ; \mathrm{K}_{2} \mathrm{HPO}_{2}, 0.1 ; \mathrm{MgSO}_{4} ; 0.7$, $\mathrm{H}_{2} \mathrm{O} ; 0.2, \mathrm{KCl}, 0.1$; chloramphenicol, 0.2 ; maneb 80, 0.02; rose bengal, 0.05; and agar, 20 (Edwards and Seddon 2001). The medium was autoclaved for $20 \mathrm{~min}$, cooled to $50^{\circ} \mathrm{C}$, amended with a predetermined volume of sterile tannic acid solution to provide a final concentration of $5 \mathrm{~g} /$ liter. Five grams of chopped strawberry plants were placed in sterile 10-cm Petri dishes and $20 \mathrm{ml}$ of BSM were poured over and allowed to solidify. Five replicate plates were used for each plant. Plates were sealed, incubated for 7 days at $23^{\circ} \mathrm{C}$, and examined for colony growth. Plates with no obvious mycelial growth were observed under a stereoscope for the presence of Botrytis conidiophores on the chopped plants above the surface of the medium. Colonies growing on BSM or Botrytis-like conidiophores on the chopped plant tissues were transferred to malt yeast agar (MYA, $20 \mathrm{~g}$ malt extract, $5 \mathrm{~g}$ yeast extract, $12 \mathrm{~g}$ agar) plates, grown until sporulation was observed, and used for Botrytis identification. In the 2013 summer season, 157 B. cinerea isolates were recovered from the four commercial fields: 88, 54, and 15 isolates in April, May, and June, respectively. The isolates were tested for fungicide sensitivity to eight fungicides using a germ tube elongation assay described below.

Detection and quantification of quiescent infections of $B$. cinerea in nursery transplants. In 2011 and 2012, 10 to 20 strawberry transplants were sampled from six different nurseries: in Canada, two from Nova Scotia, one from Ontario, and one from Quebec; and in the United States, one from North Carolina, and one from California. During the 2013-2014 season, 40 transplants were sampled from 13 different nurseries: three from North Carolina, one from California, four from Nova Scotia, two from Ontario, and three from Quebec. The transplants were sampled immediately upon arrival to Florida prior to planting. One leaf was removed from each transplant and surface-disinfested in $0.02 \%$ sodium hypochlorite for $2 \mathrm{~min}$, then rinsed twice with sterile deionized water. The leaves were frozen overnight at $-20^{\circ} \mathrm{C}$ to hasten tissue death, and then incubated over chicken wire folded in a wave shape inside clear plastic boxes $(31.5 \times 25 \times 10 \mathrm{~cm})$ with $250 \mathrm{ml}$ of deionized water at the bottom to maintain high humidity for 7 days at room temperature $\left(\sim 23^{\circ} \mathrm{C}\right)$. The leaves were examined under a stereomicroscope $(14 \times)$ for the presence of $B$. cinerea-like conidiophores. The incidence of infected leaves was recorded and $B$. cinerea isolates were transferred to MYA plates. In total, 560 isolates-30, 57, and 473 isolates in 2011, 2012, and 2013, respectively-were collected and approximately 20 isolates per cultivar/nursery combination were tested for fungicide sensitivity as described below.

Fungicide sensitivity tests. In total, $409 \mathrm{~B}$. cinerea isolates originating from nursery transplants were tested for sensitivity to eight fungicides: boscalid (Endura, BASF, Research Triangle Park, NC); fenhexamid (Elevate 50 WDG, Arysta LifeScience, San Francisco, CA); fludioxonil (Medallion, Syngenta, Greensboro, NC); fluopyram (Luna Privilege, Bayer CropScience, Research Triangle Park, NC); iprodione (Rovral, Bayer CropScience), penthiopyrad (Fontelis, DuPont, Wilmington, DE); pyraclostrobin (Cabrio EG, BASF); and pyrimethanil (Scala SC, Bayer CropScience).

Sensitivity to fenhexamid of isolates collected in 2012 and 2013 was evaluated using a mycelial growth inhibition assay because this assay was found to be more accurate than a germ tube elongation assay in isolates collected in 2011. For this, one plug (4 mm diameter) was taken with a cork borer from a 4-day-old actively growing colony on MYA and placed upside down on a 6-cm-diameter Petri dish containing potato dextrose agar (PDA) amended with $10 \mu \mathrm{g} / \mathrm{ml}$ of fenhexamid as described previously (Amiri et al. 2013). One plate was used per isolate/fungicide combination and the test was conducted twice. Sensitivity to other fungicides was evaluated using a germ-tube inhibition assay. Isolates were grown initially on MYA for 5 to 6 days until profuse sporulation was observed and a suspension of $2.5 \times 10^{5}$ conidia/ $\mathrm{ml}$ was prepared for each isolate. Three different media were used: malt extract agar (MEA; $10 \mathrm{~g}$ malt extract, $15 \mathrm{~g}$ agar) was used to test for fludioxonil at $10 \mu \mathrm{g} / \mathrm{ml}$, iprodione at $50 \mu \mathrm{g} / \mathrm{ml}$, and pyraclostrobin at $50 \mu \mathrm{g} / \mathrm{ml}$ plus $100 \mu \mathrm{g} / \mathrm{ml}$ SHAM (Acros Organics, Morris Plains, NJ); $0.5 \%$ sucrose agar for pyrimethanil at $25 \mu \mathrm{g} / \mathrm{ml}$ (Weber 2011); and yeast bacto agar (YBA; $10 \mathrm{~g}$ bacto peptone, $20 \mathrm{~g}$ sodium acetate, $10 \mathrm{~g}$ yeast extract, $15 \mathrm{~g}$ agar) was used to test for sensitivity to boscalid at $5 \mu \mathrm{g} / \mathrm{ml}$, fluopyram at $2.5 \mu \mathrm{g} / \mathrm{ml}$, and penthiopyrad at $3 \mu \mathrm{g} / \mathrm{ml}$. The discriminatory doses for boscalid, fluopyram, and penthiopyrad were selected after preliminary tests conducted using isolates with known genotypes (Amiri et al. 2014a). Tests were conducted in 15-cm-diameter Petri dishes containing the media amended with the respective discriminatory doses of each fungicide. Plates were divided into thirty squares on the bottom side to guide conidial placement and the subsequent measurements. Two 7- $\mu$ l drops of the spore suspension were placed diagonally in each square on the plates, incubated at $23^{\circ} \mathrm{C}$ for 18 to $24 \mathrm{~h}$, and conidial germination and germ tube length were evaluated microscopically by counting 100 conidia for each $B$. cinerea isolate. Germ tube elongation was rated as described previously (Weber 2011). One plate was used per isolate/fungicide combination and the test was repeated twice.

\section{Results}

Over-summering of $\boldsymbol{B}$. cinerea in strawberry fields. The frequency of $B$. cinerea propagules on strawberry plants left in the field after the regular season decreased gradually over the summer. In 2012, no Botrytis propagules were detected on plants collected in August from either commercial field (data not shown). The frequency of plants showing Botrytis propagules ranged from 40.0 to $75.0 \%$ across locations in April of 2013 (Fig. 1A). Botrytis incidence decreased in May reaching frequencies between $15.0 \%$ (FRR field) and $50.0 \%$ (CER field). In June 2013, Botrytis was detected in two fields and at frequencies of $10.0 \%$ (LFL field) and $25.0 \%$ (FRF field) (Fig. 1A). Botrytis cinerea was absent from all commercial fields surveyed in July and August of 2013.

The resistance frequency in a $B$. cinerea population of 157 isolates collected in 2013 did not decrease significantly for any of the fungicides tested over a 4-month period without fungicide spray. Thus, resistance frequency remained constantly high for pyraclostrobin $(>75.0 \%)$ from April to June (Fig. 1B). Resistance frequency to fenhexamid decreased slightly from $68.2 \%$ in April to $55.0 \%$ in May and June. Overall, resistance frequencies remained about $50.0 \%$ for pyrimethanil and about $42.0 \%$ for boscalid over the 3-month period, whereas resistance to penthiopyrad was about $20.0 \%$ in April and May but not detected in June 2013 (Fig. 1B). Resistance to fluopyram, fludioxonil, and iprodione was not detected at any sampling time (data not shown).

Incidence of $B$. cinerea quiescent infections in nursery transplants. $B$. cinerea was isolated from transplants originating from all nurseries surveyed. Overall, the incidence of B. cinerea was higher in 2013 compared with 2011 and 2012. With the exception of one nursery from Nova Scotia (I) in 2013, quiescent infection rates were higher than $20.0 \%$ in all surveyed nurseries. The frequency of plants infected with $B$. cinerea in 2011 was 22.0 and $28.6 \%$ from two Nova Scotia nurseries and $36.7 \%$ from one Quebec nursery (Table 1). In 2012, the percentages of infection were 83.3, 56.7, 55.0, 20.0, and $20.0 \%$ from Quebec, Nova Scotia, California, Ontario, and North Carolina nurseries, respectively. The frequency of infections in 2013 ranged from 2.5 to $92.5 \%$ across nurseries. In the only Californian nursery (D) surveyed, B. cinerea incidence was $76.9 \%$ in 2013 , whereas incidence ranged from 2.5 and $92.5 \%$ in Nova Scotia, 22.9 and $88.6 \%$ in North Carolina, from 58.5 to $92.5 \%$ in Quebec, and from 64.1 to $92.5 \%$ in Ontario (Table 1).

Fungicide sensitivity tests. The overall resistance frequency to fenhexamid was 16.9 in 2011, 31.8 in 2012, and 13.3\% in 2013 (Table 2). Among locations, resistance frequencies ranged from 
$0.0 \%$ in six nurseries, to $50.0 \%$ (Table 2), with most nurseries showing frequencies less than $40.0 \%$. Geographically, nurseries from Quebec had the highest frequencies of isolates resistant to fenhexamid. One nursery (B) from Nova Scotia and one (C) from Quebec were evaluated in all three years and showed variable frequencies from year to year as seen in nurseries from California (D), North Carolina (E), and Ontario (F) evaluated in 2012 and 2013.

Resistance frequencies to the QoI-pyraclostrobin were high across all nurseries surveyed in the three years. Thus, all isolates were resistant to pyraclostrobin except in four nurseries: B from Nova Scotia in 2011 and 2012; E from Ontario in 2012; and G from Nova Scotia in 2013 (Table 2). The overall resistance frequency to boscalid increased from $65.9 \%$ in 2011 to $82.5 \%$ in 2012 and to $89.6 \%$ in 2013 (Table 2). In 2011, boscalid resistance frequencies ranged from 55.6 to $78.6 \%$, from 62.5 to $86.4 \%$ in 2012 , and from 25 to $100 \%$ in 2013. The increasing pattern of boscalid resistance frequencies were observed across nurseries surveyed during two or three successive seasons: in nursery B from Nova Scotia, frequency increased from
$55.6 \%$ in 2011 to $87.2 \%$ in 2013; and in nursery C from Quebec, from $78.6 \%$ in 2011 to $94.7 \%$ in 2013 . Similar trends were observed in nurseries D, E, and F surveyed in 2012 and 2013 (Table 2). Only one nursery $(\mathrm{G})$ from Nova Scotia had no resistance to fenhexamid and low resistance frequencies $(<25 \%)$ to boscalid and pyraclostrobin. Of the 409 isolates tested, 16 (3.9\%) were sensitive to both pyraclostrobin and boscalid, 20 (4.9\%) were resistant to pyraclostrobin but sensitive to boscalid, two isolates $(0.5 \%)$ resistant to boscalid but sensitive to pyraclostrobin, and the remaining isolates were resistant to both fungicides. Only one isolate resistant to the SDHI penthiopyrad was found in nursery $\mathrm{N}$ in 2013 (data not shown).

The overall frequency of isolates resistant to pyrimethanil was $35.0 \%$ in $2011,25.1 \%$ in 2012, and $39.4 \%$ in 2013 (Table 2). One nursery from North Carolina $(\mathrm{J})$ had the highest $(75.0 \%)$ pyrimethanil resistance frequency, while all the other nurseries had frequencies below $60.0 \%$. A single nursery from Nova Scotia $(G)$ had the lowest frequencies of resistance for pyrimethanil $10.0 \%$, pyraclostrobin $20.0 \%$, and boscalid $25.0 \%$. Resistance to fludioxonil was not
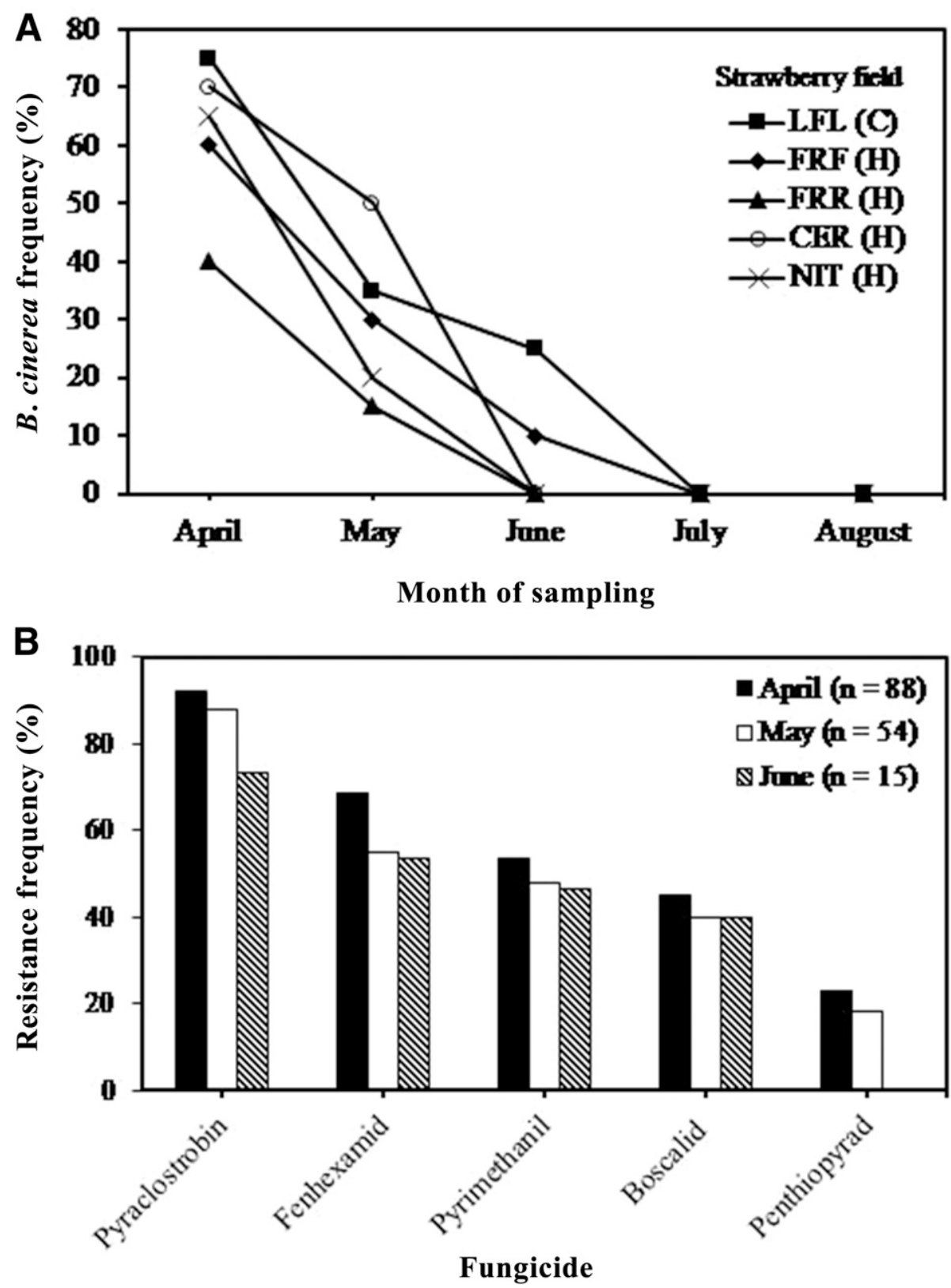

Fig. 1. A, Monthly incidence of Botrytis cinerea on strawberry plants left over the summer in five strawberry fields in 2013. Data are the mean 200 measurements per field using 40 plants and five replicate plates. B, Change in resistance frequency (\%) for five fungicides in B. cinerea isolates collected between March and April of 2013. 
detected and was very low to fluopyram $(0.2 \%)$, penthiopyrad $(0.2 \%)$, and iprodione $(2.4 \%)$ from all nurseries tested (data not shown).

Overall, only a few nurseries showed isolates sensitive (S) to all fungicides, namely, B from Nova Scotia in 2011-2012 and G from Nova Scotia in 2013 (Fig. 2). Isolates of B. cinerea with multifungicide resistance (MFR) were found in different nurseries surveyed over three years (Fig. 2).

In 2011-2012, resistance to two fungicides (MFR2) was widespread in Nova Scotia, whereas resistance to three fungicides (MFR3) was observed in all nurseries tested, predominantly from
California (D). Nursery D was the one with the highest frequency of FR1 phenotype, 36.4\%. Resistance to four fungicides (MFR4) was observed in $50.0 \%$ of the isolates from Ontario (C) (Fig. 2A). In 2013, resistance to three fungicides (MFR3) was the most commonly observed phenotype across nurseries (Fig. 2B). Frequency of isolates from California resistant to two (MFR2), three (MFR3), or four (MFR4) fungicides were $33.9 \%, 45.8 \%$, and $18.6 \%$, respectively. One nursery from Ontario had $5.0 \%$ of isolates resistant to six fungicides (MFR6); however, the other nursery from the same region had MFR2, MFR3, and MFR4 isolates. In Quebec, the majority of isolates were resistant to three fungicides (MFR3) for all nurseries

Table 1. Frequency of strawberry transplants from different nurseries infected with Botrytis cinerea in 2011, 2012, and 2013

\begin{tabular}{|c|c|c|c|c|c|}
\hline Year & Region & Nursery & No. of plants sampled & No. of isolates & Plants infected $(\%)$ \\
\hline \multirow[t]{3}{*}{2011} & Nova Scotia & A & 50 & 11 & 22.0 \\
\hline & Nova Scotia & B & 28 & 8 & 28.6 \\
\hline & Quebec & $\mathrm{C}$ & 30 & 11 & 36.7 \\
\hline \multirow[t]{5}{*}{2012} & California & $\mathrm{D}$ & 20 & 11 & 55.0 \\
\hline & Nova Scotia & B & 30 & 17 & 56.7 \\
\hline & Quebec & $\mathrm{C}$ & 30 & 25 & 83.3 \\
\hline & Ontario & $\mathrm{E}$ & 10 & 2 & 20.0 \\
\hline & North Carolina & $\mathrm{F}$ & 10 & 2 & 20.0 \\
\hline \multirow[t]{13}{*}{2013} & California & $\mathrm{D}$ & 108 & 83 & 76.9 \\
\hline & Nova Scotia & $\mathrm{G}$ & 40 & 30 & 75.0 \\
\hline & Nova Scotia & $\mathrm{H}$ & 40 & 37 & 92.5 \\
\hline & Nova Scotia & I & 40 & 1 & 2.5 \\
\hline & Nova Scotia & B & 70 & 52 & 74.3 \\
\hline & North Carolina & $\mathrm{J}$ & 35 & 8 & 22.9 \\
\hline & North Carolina & K & 71 & 35 & 49.3 \\
\hline & North Carolina & F & 35 & 31 & 88.6 \\
\hline & Quebec & $\mathrm{L}$ & 40 & 28 & 70.0 \\
\hline & Quebec & M & 41 & 24 & 58.5 \\
\hline & Quebec & $\mathrm{C}$ & 74 & 57 & 77.0 \\
\hline & Ontario & $\mathrm{N}$ & 40 & 37 & 92.5 \\
\hline & Ontario & $\mathrm{E}$ & 78 & 50 & 64.1 \\
\hline
\end{tabular}

Table 2. Resistance frequency to eight different fungicides of Botrytis cinerea isolates from nurseries

\begin{tabular}{|c|c|c|c|c|c|c|c|}
\hline \multirow[b]{2}{*}{ Year } & \multirow[b]{2}{*}{ Region } & \multirow[b]{2}{*}{ Nursery } & \multirow[b]{2}{*}{ Total isolates } & \multicolumn{4}{|c|}{ Frequency of resistant isolates $(\%)^{\mathrm{z}}$} \\
\hline & & & & Fenhexamid & Pyrimethanil & Pyraclostrobin & Boscalid \\
\hline \multirow[t]{4}{*}{2011} & Nova Scotia & A & 11 & 18.2 & 40.0 & 100.0 & 63.6 \\
\hline & Nova Scotia & $\mathrm{B}$ & 8 & 11.1 & 11.1 & 77.8 & 55.6 \\
\hline & Quebec & $\mathrm{C}$ & 11 & 21.4 & 53.8 & 100.0 & 78.6 \\
\hline & Avg. & & & 16.9 & 35.0 & 92.6 & 65.9 \\
\hline \multirow[t]{6}{*}{2012} & California & D & 11 & 9.1 & 50.0 & 100.0 & 63.6 \\
\hline & Nova Scotia & $\mathrm{B}$ & 17 & 0.0 & 18.8 & 93.8 & 62.5 \\
\hline & Quebec & $\mathrm{C}$ & 25 & 50.0 & 56.5 & 100.0 & 86.4 \\
\hline & Ontario & $\mathrm{E}$ & 2 & 100.0 & 0.0 & 50.0 & 100.0 \\
\hline & North Carolina & $\mathrm{F}$ & 1 & 0.0 & 0.0 & 100.0 & 100.0 \\
\hline & Avg. & & & 31.8 & 25.1 & 88.8 & 82.5 \\
\hline \multirow[t]{14}{*}{2013} & California & $\mathrm{D}$ & 59 & 8.5 & 44.1 & 100.0 & 89.8 \\
\hline & Nova Scotia & G & 20 & 0.0 & 10.0 & 20.0 & 25.0 \\
\hline & Nova Scotia & $\mathrm{H}$ & 20 & 0.0 & 40.0 & 100.0 & 85.0 \\
\hline & Nova Scotia & I & 1 & 0.0 & 0.0 & 100.0 & 100.0 \\
\hline & Nova Scotia & $\mathrm{B}$ & 39 & 10.3 & 38.5 & 100.0 & 87.2 \\
\hline & North Carolina & $\mathrm{J}$ & 8 & 0.0 & 75.0 & 100.0 & 100.0 \\
\hline & North Carolina & $\mathrm{K}$ & 20 & 15.0 & 45.0 & 100.0 & 95.0 \\
\hline & North Carolina & $\mathrm{F}$ & 18 & 5.6 & 55.6 & 100.0 & 100.0 \\
\hline & Quebec & $\mathrm{L}$ & 20 & 50.0 & 55.0 & 100.0 & 95.0 \\
\hline & Quebec & M & 20 & 10.0 & 25.0 & 100.0 & 100.0 \\
\hline & Quebec & $\mathrm{C}$ & 38 & 31.6 & 34.2 & 100.0 & 94.7 \\
\hline & Ontario & $\mathrm{N}$ & 20 & 5.0 & 30.0 & 100.0 & 95.0 \\
\hline & Ontario & $\mathrm{E}$ & 40 & 37.5 & 60.0 & 100.0 & 97.5 \\
\hline & Avg. & & & 13.3 & 39.4 & 93.8 & 89.6 \\
\hline
\end{tabular}

${ }^{\mathrm{z}}$ The concentrations of fungicides used were $5 \mu \mathrm{g} / \mathrm{ml}$ for boscalid (Endura), $10 \mu \mathrm{g} / \mathrm{ml}$ for fenhexamid (Elevate $50 \mathrm{WDG}$ ), and pyraclostrobin (Cabrio EG), and 25 $\mu \mathrm{g} / \mathrm{ml}$ for pyrimethanil (Scala SC). Sensitivity data for fluopyram $(5 \mu \mathrm{g} / \mathrm{ml})$, penthiopyrad $(5 \mu \mathrm{g} / \mathrm{ml})$, iprodione $(50 \mu \mathrm{g} / \mathrm{ml})$, and fludioxonil (10 $\mu \mathrm{g} / \mathrm{ml}) \mathrm{were} \mathrm{not}$ shown because resistance was not detected or the frequency was low. 
tested, MFR3 phenotype included resistance to pyraclostrobin, Boscalid, and either fenhexamid or pyrimethanil. Two North Carolina nurseries had more than $55.0 \%$ of their isolates resistant to three fungicides (MFR3); whereas in the third nursery, the MFR4 phenotype was predominant $(75.0 \%)$. The results from Nova Scotia were noteworthy because one nursery had $30.0 \%$ of isolates sensitive (S) to all fungicides and $35.0 \%$ of isolates resistant to only one fungicide (fenhexamid); this nursery also had $10.0 \%$ of isolates resistant to two fungicides (fenhexamid and pyraclostrobin or boscalid), and the remaining isolates were resistant to either three or four fungicides, including pyrimethanil.

Overall, the most common phenotype of multifungicide resistance observed across nurseries was MFR2, with $25.0 \%$ of $B$. cinerea isolates resistant to boscalid and pyraclostrobin (Fig. 3). Twenty-two percent of the isolates were either MFR3 or MFR4, with multiresistance to boscalid, pyraclostrobin, fenhexamid (MFR3), and pyrimethanil

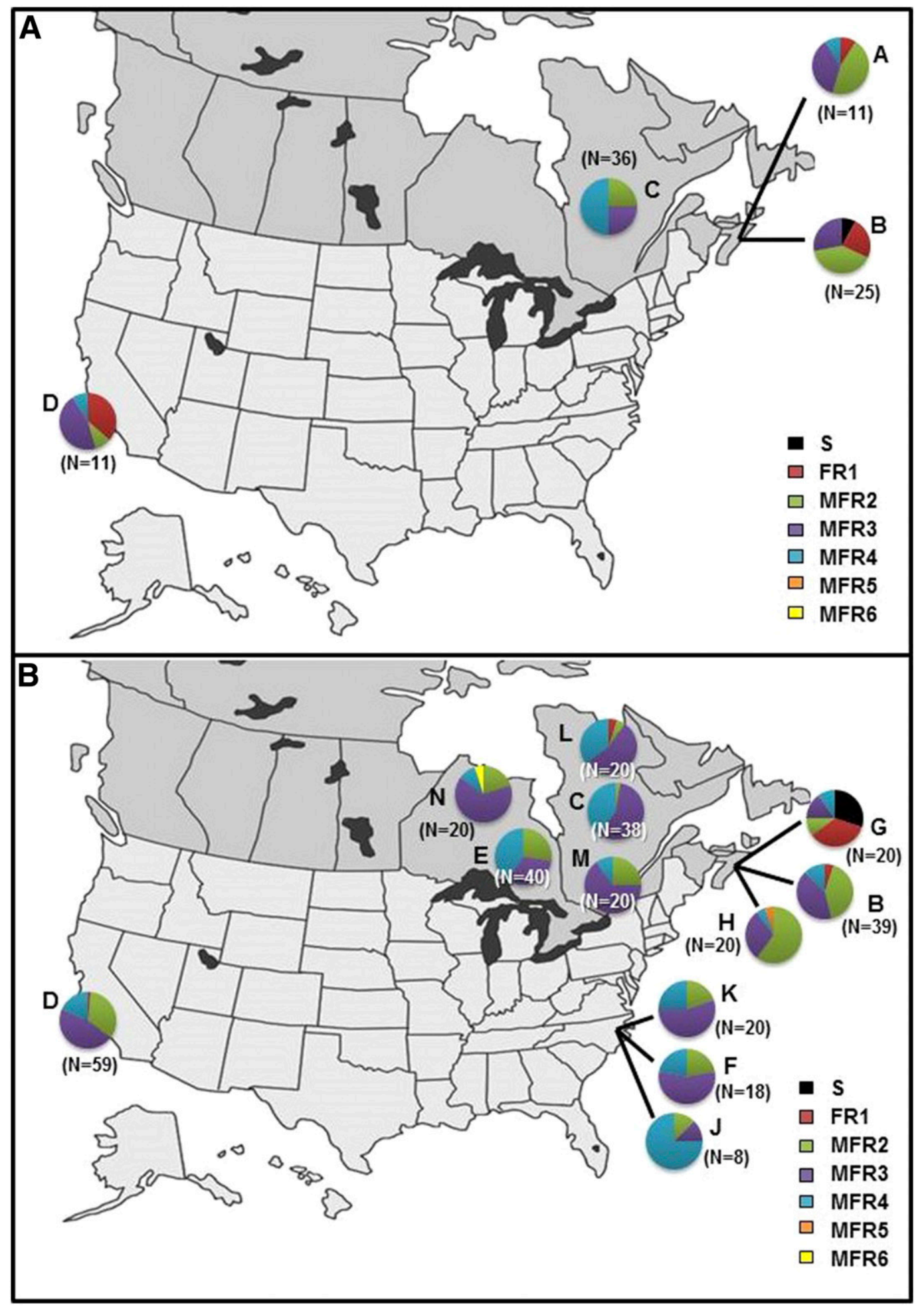

Fig. 2. Frequency of multifungicide resistance (MFR) phenotypes of Botrytis cinerea from strawberry transplants collected from different nurseries from California, North Carolina, Nova Scotia, Quebec, and Ontario in A, 2011-2012, and B, 2013. The fungicides tested were fenhexamid, pyrimethanil, pyraclostrobin, boscalid, fluopyram, penthiopyrad, iprodione, and fludioxonil ( $\mathrm{S}=$ sensitive, FR1 = resistant to one fungicide, MFR2 = resistant to two fungicides, MFR3 = resistant to three fungicides, MFR4 = resistant to four fungicides, MFR5 = resistant to five fungicides, MFR6 = resistant to six fungicides). $\mathrm{N}$ is the number of isolates evaluated in each location. The letter next to each pie refers to the nursery code. 
(MFR4). Another frequent MFR3 phenotype was $B$. cinerea isolates resistant to boscalid, pyraclostrobin, and pyrimethanil (19.3\%). All the other phenotypes were represented by less than $3.5 \%$ of the isolates.

\section{Discussion}

This study demonstrates that $B$. cinerea does not over-summer on strawberry plants left in the field between seasons and that nursery transplants are the most important source of primary inoculum of $B$. cinerea in strawberry fields in Florida and likely other southern growing regions. Although nursery transplants have been reported to carry quiescent infections of B. cinerea (Boff et al. 2001; Carver et al. 1998), to our knowledge this is the first indication that fungicide-resistant populations of $B$. cinerea are annually introduced into strawberry fields through transplants. This important finding should alert nurseries and strawberry growers to the need to adopt improved and new disease management strategies.

At the end of the strawberry season, which is usually mid- to lateMarch in Florida, many growers keep the same plastic mulch for the following season; strawberry plants are killed but removed only before the beginning of the new planting season. In this study, we found that $B$. cinerea does not survive as conidia or mycelium on strawberry plants left in the fields. The fungus was detected on plants collected in March and April, its incidence decreased sharply in June, and it was absent on plants surveyed in July and August for successive seasons. Previous studies investigated the overwintering of $B$. cinerea in perennial strawberry systems in Norway and reported the presence of up to $350,000 \mathrm{~B}$. cinerea propagules per square meter of plant row on dead leaves, but less on mummified fruit (Stromeng et al. 2009). In a study more relevant to ours and conducted in southern Spain, B. cinerea survived less than 28 days postinoculation in the soil when temperatures were above $30^{\circ} \mathrm{C}$ (Moyano and Melgarejo 2002). It is likely that $B$. cinerea is capable of enduring freezing temperatures but not temperatures above $30^{\circ} \mathrm{C}$ and very common in Florida from June to August. This observation is also supported by the fact that $B$. cinerea is seldom problematic on summer or early fall susceptible crops such as tomato in Florida. Beside high temperatures, Florida is known for its high ultra-violet index, especially during the summer, which may constitute an additional barrier for the fungus to over-summer in the field.

Strawberry production in the southern United States starts from either plugs or bare-root transplants produced in nurseries in Canada and northern United States or at high elevation. The transplants shipped to Florida are usually the third or fourth generation from the original mother plant. Some nurseries propagate all the plant generations but others acquire plant stock for multiplication from other nursery sources, mainly large nurseries in California. Even though strawberry propagation systems vary, it is common that at least the third and fourth generations of transplants are multiplied in open fields, and thus are subject to infections by $B$. cinerea and other pathogens (Rahman et al. 2015). In our preliminary study conducted on small number of nurseries and isolates, we found that 20 to $55 \%$ of transplants infected with $B$. cinerea were resistant to various common fungicides used in Florida and other strawberry growing regions (Oliveira et al. 2013). Herein, we confirm the widespread presence of $B$. cinerea on transplants and show evidence that these populations are resistant to one or multiple fungicides simultaneously.

Some of the fungicides that control $B$. cinerea in the field are also used in the nurseries to control other diseases such as anthracnose, caused by Colletotrichum spp., and powdery mildew, caused by Podosphaera aphanis (Mercier et al. 2010; Rahman et al. 2015; Whitaker et al. 2015); thus, nontarget sprays are probably one factor that may have increased risks of resistance development in $B$. cinerea populations from nurseries. It is likely that the selection pressure on field populations has resulted in resistant isolates that are perpetuated over propagation cycles. Consequently, strawberry growers receive plants already infected with resistant isolates from which a portion can persist throughout the season in the growing regions. This may explain why resistance levels found in nurseries were not much different than those recently reported in Florida and South and North Carolina strawberry fields (Amiri et al. 2014a; Fernandez-Ortuno et al. 2012).

Botrytis cinerea populations with resistance to the SDHI boscalid were found at high frequencies in this study, similar to those reported at the end of the growing seasons in commercial strawberry fields in Florida (Amiri et al. 2013; 2014b). Slightly lower frequencies were reported from other regions, namely France and Germany (72.0\%) (Leroux et al. 2010), California (66.0\%) (Mercier et al. 2010), and the Carolinas (61.5\%) (Fernandez-Ortuno et al. 2012). The later studies were performed prior to the one done in Florida, which may explain the relatively lower frequencies. Resistance to the new SDHIs penthiopyrad and fluopyram was seldom found in populations from nurseries. Thus, only two $(0.5 \%)$ isolates of 409 were resistant to either penthiopyrad only or fluopyram. This is much lower than 3 and $15 \%$ resistance to fluopyram and penthiopyrad, respectively, reported recently in Florida commercial fields (Amiri et al. 2014b). These two newer SDHIs in addition to fluxapyroxad (Merivon) would be alternatives to current SDHIs in strawberry fields if used very

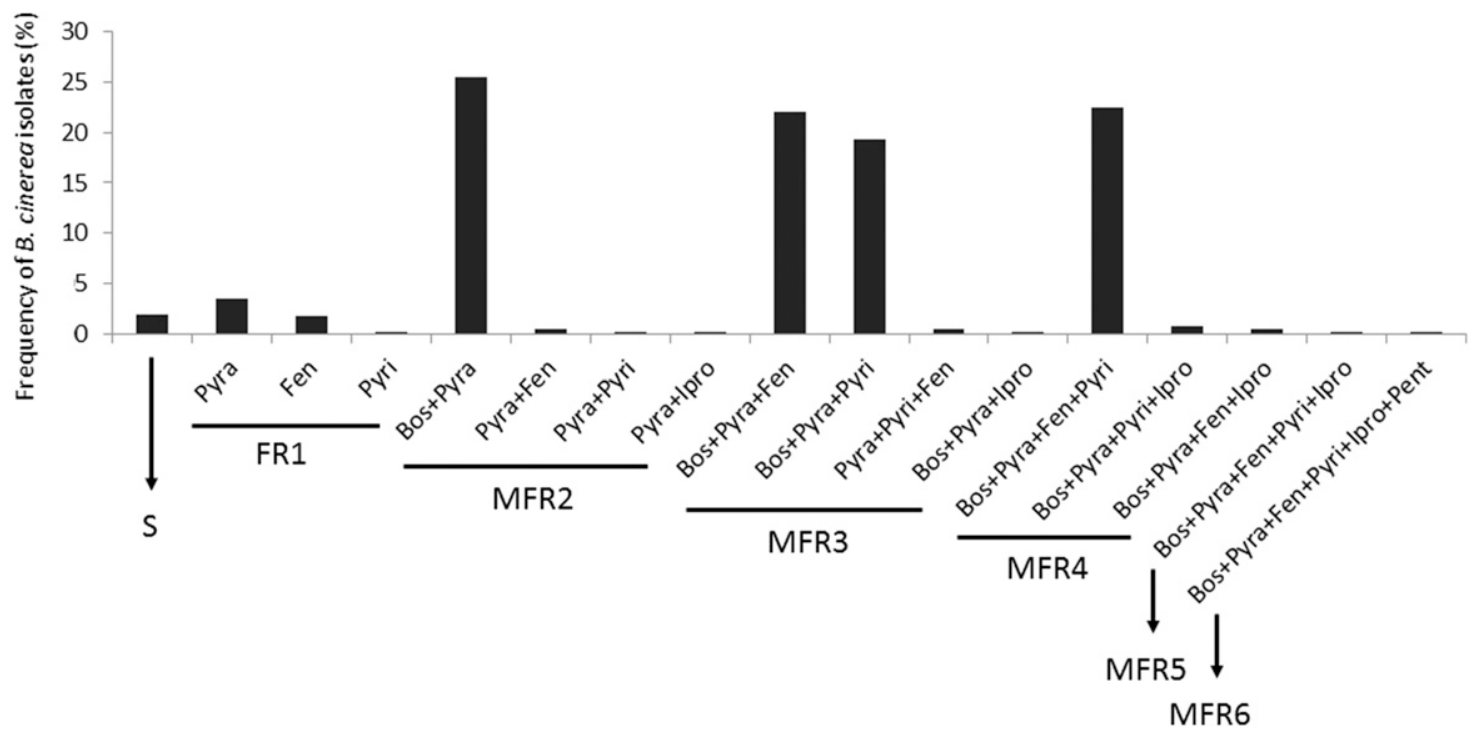

Fig. 3. Distribution of multifungicide resistance (MFR) phenotypes of $B$. cinerea isolates from nurseries $(n=409)$ to six different fungicides. Pyra, Fen, Pyri, Bos, Ipro, and Pent indicate Pyraclostobin, Fenhexamid, Pyrimethanil, Boscalid, Iprodione, and Penthiopyrad, respectively. S indicates sensitive, FR1 indicates resistant to one fungicide, and MFR2, MFR3, MFR4, MFR5, and MFR6 indicate isolates that are resistant to two, three, four, five, or six fungicides, respectively. 
carefully. On the other hand, resistance to the QoI-pyraclostrobin was found at very high frequencies $(>90 \%)$ in almost all nurseries surveyed. Besides pyraclostrobin, other QoIs are used in nurseries to control powdery mildew and other pathogens for almost two decades which has certainly led to such high resistance frequencies. Pristine (pyraclostrobin + boscalid) has also been used for over a decade and is certainly the cause of such high frequencies for both pyraclostrobin and boscalid. This raises a question about the risks of using existing premixed fungicides but also for some formulations that are being labeled to control gray mold and other pathogens in strawberry. Premixing two high-risk chemical groups such as the QoIs and SDHIs or SDHIs with anilinopyrimidines (pyrimethanil) such as in Luna Tranquility (fluopyram + pyrimethanil) and Luna Sensation (fluopyram + trifloxystrobin) can constitute an additional risk especially when targeting a high-risk pathogen such as $B$. cinerea.

Pyrimethanil, an anilino-pyrimidine, had an overall resistance frequency of $33.2 \%$, a frequency similar to that reported in Chile (Esterio et al. 2011), whereas in Greece (Myresiotis et al. 2007), $49.0 \%$ of $B$. cinerea isolates were resistant to pyrimethanil. Due to the existing resistance to boscalid, pyraclostrobin, and pyrimethanil found in this study and previously (Amiri et al. 2013), the commercial products Pristine (boscalid + pyraclostrobin) and Scala (pyrimethanil) are no longer recommended for gray mold management on strawberries in Florida (Cordova et al. 2017a). One nursery (G) had lower resistance frequencies to these three active ingredients $(25.0 \%, 20.0 \%$, and $10.0 \%)$ than the other nurseries tested. Future studies should include obtaining the spray records from all the nurseries surveyed to compare the differential $B$. cinerea sensitivity.

No resistance to fludioxonil was found in $B$. cinerea populations from nurseries surveyed over three years. Interestingly in 2013, one nursery showed $35 \%$ of isolates with reduced sensitivity to fludioxonil (extended germ tube at $0.1 \mu \mathrm{g} / \mathrm{ml}$; data not shown). It is very likely that this nursery has sprayed fludioxonil-formulated fungicides such as Switch at least in 2013 or maybe even in previous seasons to result in such relatively high frequency of isolates shifting toward resistance. Based on the findings from our study, it becomes very crucial that fludioxonil-formulated fungicides are not used in nurseries but rather should be reserved for commercial strawberry fields because of the very limited options available there. Recent field trials indicated that Switch (fludioxonil + cyprodinil) provides the best control of gray mold in Florida strawberry fields (Cordova et al. 2014), which is due to the high efficacy of fludioxonil and absence of resistance to it and not to cyprodinil for which resistance is widespread in Florida (Amiri et al. 2013) and in the southeastern United States (Fernandez-Ortuno et al. 2014). Although some recent studies occasionally have reported very low resistance frequencies, e.g., in strawberry (Fernandez-Ortuno et al. 2014), it is more likely that fludioxonil will constitute the backbone of gray mold management strategies in the years to come.

Resistance to the sterol biosynthesis inhibitor (SBI) fenhexamid in nursery isolates varied from zero to $50.0 \%$ with an overall resistance frequency of $18.2 \%$. Fenhexamid is a fungicide with activity against $B$. cinerea and some other fungi in the Sclerotiniaceae family only. The variability in resistance frequencies observed between nurseries herein may suggest that it is being used by some nurseries especially when they use closer planting or if continuous bloom occurs and flowers are not removed. Since the population resistant to this product is at moderate levels and the most common commercial formulation is in a premix with the multisite captan (Captevate), it is very crucial to avoid its use in the nurseries and reserve it for commercial fields to extend its effective life and slowdown the selection for additional resistant populations in downstream production systems.

Although resistance to some fungicides in $B$. cinerea populations from nurseries was expected, the presence of multifungicide resistance (MFR) at such frequencies found herein was overwhelming and will constitute a significant challenge for managing gray mold in the fruit production fields. Resistance to up to six fungicides was observed in the current study; however, the most prevalent MFR population (42.1\%) was MFR3 as a result of widespread resistance to pyraclostrobin, boscalid, pyrimethanil and fenhexamid.
The multifungicide phenotype with the highest frequency of $B$. cinerea isolates was MFR2, with resistance to boscalid and pyraclostrobin. These results are in accordance with reports of widespread distribution of MFR in Florida fields in 2013 (Amiri et al. 2013). The latter also found a majority of isolates have resistance to two (MFR2, 25\%) and three fungicide (MFR3, 40\%) of six fungicides tested. Recent studies by Fernandez-Ortuno et al. $(2014,2016)$ found that the most frequent resistance profile $(55.8 \%)$ was to three fungicides pyraclostrobin, boscalid and cyprodinil. Development of resistance to multiple fungicides simultaneously is not very common in many pathogens is most likely from the potential impact for multiple mutations on such populations. However, because of its genetic plasticity and high mutation frequency, $B$. cinerea has shown the ability to adapt quickly to multiple fungicides in a relatively short period. Although mechanisms such as stepwise accumulation, where a population resistant to one fungicide may adapt better to develop resistance quickly to other fungicides, has been suggested ( $\mathrm{Li}$ et al. 2014), additional research is needed to understand why only a few species such as $B$. cinerea can evolve this way.

As a result of our findings, drastic changes in disease management strategies is highly recommended to insure sustainable production in commercial strawberry fields. One strategy could consist of the nurseries relying more in the multisite fungicides, especially thiram, which has a better efficacy against $B$. cinerea than captan on strawberry leaves (Amiri and Peres, unpublished data). Sanitation and cultural practices such as removing flowers and avoiding fruiting in transplant production fields should also be enforced by nursery growers to reduce inoculum survival and dispersal of Botrytis as well as other diseases. Growers of commercial fruit fields can significantly reduce the primary $B$. cinerea inoculum by either dipping them in fungicides prior to planting or spraying immediately after planting. Single-site fungicides such as iprodione, fluopyram, fludioxonil and the multisite thiram have been shown to be effective at this early stage (Amiri and Peres, unpublished data) but should be used very carefully to avoid early selection of resistant populations. At midseason and peak-bloom period, the recommendation is to use existing tools such as the Strawberry Advisory System (http://www.agroclimate.org/tools/sas) (Cordova et al. 2017b) to time fungicide applications and avoid unnecessary sprays that can increase selection pressure.

There is an ongoing effort to improve collaboration and communication between nurseries, scientists, and strawberry growers to use existing effective tools such as the Strawberry Advisory System in the nurseries. Additionally, research and industry resources should be invested in the registration of products with different modes of action than the ones used in the fruit production fields exclusively for nursery use.

\section{Literature Cited}

Amiri, A., Heath, S. M., and Peres, N. A. 2013. Phenotypic characterization of multifungicide resistance in Botrytis cinerea isolates from strawberry fields in Florida. Plant Dis. 97:393-401.

Amiri, A., Heath, S. M., and Peres, N. A. 2014a. Resistance to fluopyram, fluxapyroxad, and penthiopyrad in Botrytis cinerea from strawberry. Plant Dis. 98:532-539.

Amiri, A., and Peres, N. A. 2014. Diversity in the erg27 gene of Botrytis cinerea field isolates from strawberry defines different levels of resistance to the hydroxyanilide fenhexamid. Plant Dis. 98:1131-1137.

Amiri, A., Zuniga, A., and Peres, N. A. 2014b. Evaluation of rotational programs to extend the life of new succinate-dehydrogenase inhibitors for control of Botrytis cinerea in strawberry. Phytopathology 104:S3.8.

Boff, P., Kastelein, P., de Kraker, J., Gerlagh, M., and Kohl, J. 2001. Epidemiology of grey mould in annual waiting-bed production of strawberry. Eur. J. Plant Pathol. 107:615-624.

Carver, L. M. B., Louws, F. J., and Fernandez, G. E. 1998. In vitro resistance of Botrytis cinerea from strawberry to the fungicides benomyl, iprodione, and vinclozolin. Phytopathology 88:S13.

Cordova, L. G., Amiri, A., and Peres, N. A., 2017a. Effectiveness of fungicide treatments following the Strawberry Advisory System for control of Botrytis fruit rot in Florida. Crop Prot. 100:163-167.

Cordova, L. G., Madden, L. V., Amiri, A. Schnabel, G., and Peres, N. A. 2017b Meta-analysis of a web-based disease forecast system for control of anthracnose and Botrytis fruit rots of strawberry in southeastern United States. Plant Dis. (in press). doi:10.1094/PDIS-04-17-0477-RE 
Cordova, L., Zuniga, A., Mertely, J., and Peres, N. 2014. Evaluation of products for the control of Botrytis fruit rot in annual strawberry, 2013-2014. Plant Dis. Manag. Rep. doi:10.1094/PDMR08

Edwards, S. G., and Seddon, B. 2001. Selective media for the specific isolation and enumeration of Botrytis cinerea conidia. Lett. Appl. Microbiol. 32:63-66.

Esterio, M., Ramos, C., Walker, A. S., Fillinger, S., Leroux, P., and Auger, J. 2011. Phenotypic and genetic characterization of Chilean isolates of Botrytis cinerea with different levels of sensitivity to fenhexamid. Phytopathol. Mediterr. 50: 414-420.

Fernández-Ortuño, D., Chen, F. P., and Schnabel, G. 2012. Resistance to pyraclostrobin and boscalid in Botrytis cinerea isolates from strawberry fields in the Carolinas. Plant Dis. 96:1198-1203.

Fernández-Ortuño, D., Grabke, A., Bryson, P. K., Amiri, A., Peres, N. A., and Schnabel, G. 2014. Fungicide resistance profiles in Botrytis cinerea from strawberry fields of seven southern U.S. states. Plant Dis. 98:825-833.

Fernández-Ortuño, D., Tores, J. A., Chamorro, M., Perez-Garcia, A., and de Vicente, A. 2016. Characterization of resistance to six chemical classes of site-specific fungicides registered for gray mold control on strawberries in Spain. Plant Dis. 100:2234-2239.

FRAC. 2015. Fungicide Resistance Action Committee (FRAC) Code List 2015: Fungicides sorted by mode of action (including FRAC Code numbering). CropLife Int., Brussels, Belgium.

Gilreath, J. P., Santos, B. M., Noling, J. W., Locascio, S. J., Dickson, D. W., Rosskopf, E. N., and Olson, S. M. 2006. Performance of containerized and bare-root transplants with soil fumigants for Florida strawberry production. HortTechnology 16:461-465.

Grabke, A., and Stammler, G. 2015. A Botrytis cinerea population from a single strawberry field in Germany has a complex fungicide resistance pattern. Plant Dis. 99:1078-1086.

Kim, Y. K., and Xiao, C. L. 2010. Resistance to pyraclostrobin and boscalid in populations of Botrytis cinerea from stored apples in Washington state. Plant Dis. 94:604-612.

Leroux, P., Gredt, M., Leroch, M., and Walker, A. S. 2010. Exploring mechanisms of resistance to respiratory inhibitors in field strains of Botrytis cinerea, the causal agent of gray mold. Appl. Environ. Microbiol. 76:6615-6630.

Li, X., Fernandez-Ortuno, D., Chen, S., Grabke, A., Luo, C.-X., Bridges, W. C., and Schnabel, G. 2014. Location-specific fungicide resistance profiles and evidence for stepwise accumulation of resistance in Botrytis cinerea. Plant Dis. 98:1066-1074.

MacKenzie, S. J., and Peres, N. A. 2012. Use of leaf wetness and temperature to time fungicide applications to control Botrytis fruit rot of strawberry in Florida. Plant Dis. 96:529-536.

Mercier, J., Kong, M., and Cook, F. 2010. Fungicide resistance among Botrytis cinerea isolates from California strawberry fields. Plant Health Prog. doi: 10.1094/PHP-2010-0806-01-RS

Mertely, J. C., MacKenzie, S. J., and Legard, D. E. 2002. Timing of fungicide applications for Botrytis cinerea based on development stage of strawberry flowers and fruit. Plant Dis. 86:1019-1024.

Moyano, C., and Melgarejo, P. 2002. Survival of Botrytis cinerea in soil in southeastern Spain. Phytopathol. Z. 150:536-540.

Myresiotis, C. K., Karaoglanidis, G. S., and Tzavella-Monari, K. 2007. Resistance of Botrytis cinerea isolates from vegetable crops to anilinopyrimidine, phenylpyrrole, hydroxyanilide, benzimidazole, and dicarboximide fungicides. Plant Dis. 91:407-413.

Oliveira, M. S., Amiri, A., and Peres, N. A. 2013. The role of nursery plants as a potential source of inoculum for Botrytis cinerea and its impact on fungicide sensitivity. Phytopathology 103:S2.107.

Oliveira, M. S., and Peres, N. A. 2014. Strawberry nursery plants as a source of Botrytis cinerea isolates resistant to fungicides. Phytopathology 104:86-87.

Rahman, M., Ojiambo, P., and Louws, F. 2015. Initial inoculum and spatial dispersal of Colletotrichum gloeosporioides, the causal agent of strawberry anthracnose crown rot. Plant Dis. 99:80-86.

Strømeng, G. M., Hjeljord, L. G., and Stensvand, A. 2009. Relative contribution of various sources of Botrytis cinerea inoculum in strawberry fields in Norway. Plant Dis. 93:1305-1310.

Sutton, J. C. 1998. Botrytis fruit rot (gray mold) and blossom blight. Pages 28-31 in: Compendium of Strawberry Diseases. J. L. Maas, ed. American Phytopathological Society, St. Paul, MN.

Weber, R. W. S. 2011. Resistance of Botrytis cinerea to multiple fungicides in northern German small-fruit production. Plant Dis. 95:1263-1269.

Whitaker, V. M., Boyd, N. S., Peres, N. A., and Smith, H. A. 2015. Strawberry production. Pages 189-199 in: Vegetable Production Handbook of Florida G. E. Vallad, J. H. Freeman and P. J. Dittmar, eds. Univ. of Florida-IFAS Ext., Gainesville, FL. 